Louisiana State University

LSU Digital Commons

Faculty Publications

Department of Oceanography \& Coastal

Sciences

3-1994

\title{
A Rationale for Coastal Wetland Restoration through Spoil Bank Management in Louisiana, USA
}

R. Eugene Turner

euturne@lsu.edu

E. M. Swenson

J. M. Lee

Follow this and additional works at: https://digitalcommons.Isu.edu/oceanography_coastal_pubs

Part of the Oceanography Commons

\section{Recommended Citation}

Turner, R., Swenson, E. M., \& Lee, J. M. (1994). A Rationale for Coastal Wetland Restoration through Spoil Bank Management in Louisiana, USA. Environmental Management, 18 (2), 271-282. Retrieved from https://digitalcommons.Isu.edu/oceanography_coastal_pubs/153

This Article is brought to you for free and open access by the Department of Oceanography \& Coastal Sciences at LSU Digital Commons. It has been accepted for inclusion in Faculty Publications by an authorized administrator of LSU Digital Commons. For more information, please contact ir@lsu.edu. 


\section{A Rationale for Coastal Wetland Restoration through Spoil Bank Management in Louisiana, USA}

\author{
R. EUGENE TURNER \\ E. M. SWENSON \\ J. M. LEE* \\ Coastal Ecology Institute and \\ Department of Oceanography and Coastal Sciences \\ Louisiana State University \\ Baton Rouge, Louisiana 70803, USA
}

\section{ABSTRACT / The rationale and outline of an} implementation plan for restoring coastal wetlands in Louisiana is presented. The rationale for the plan is based on reversing the consequences of documented cause-and-effect relationships between wetland loss and hydrologic change. The main feature is to modify the extensive interlocking network of dredged spoil deposits, or spoil banks, by reestablishing a more natural water flow at moderate flow velocity $(<5 \mathrm{~cm} / \mathrm{sec})$. Guidelines for site selection from thousands of potential sites are proposed Examples of suitable sites are given for intermediate marshes. These sites exhibit rapid deterioration following partial or complete hydrologic impoundment, implying a strong hydrologic, rather than sedimentological, cause of wetland deterioration.

We used an exploratory hydrologic model to guide determination of the amount of spoil bank to be removed. The results from an economic model indicated a very effective cost-benefit ratio. Both models and practical experience with other types of restoration plans, in Louisiana and elsewhere, exhibit an economy of scale wherein larger projects are more cost effective than smaller projects. However, in contrast to these other projects, spoil bank management may be 100 to 1000 times more cost effective and useful in wetland tracts $<1000$ ha in size. Modest spoil bank management at numerous small wetland sites appears to offer substantial positive attributes compared to alternative and more intensive management at a few larger wetland sites.
Wetland loss is a national concern (National Research Council 1991) and of particular interest in Louisiana where there are relatively high losses (e.g., $0.86 \% / y r$ from 1956 to 1978) (Turner 1990). Dredging is a conspicuous human activity affecting Louisiana's coastal wetlands, is principally related to oil and gas recovery efforts, and results in large areas of canals and residual dredged spoil deposits, or spoil banks $(80,426$ ha, equivalent to $8.6 \%$ of the wetland area in 1978) (Baumann and Turner 1990). The aggregate length of these spoil banks in Louisiana is in the neighborhood of $19,000 \mathrm{~km}$ and to remove all of them would cost about as much as to build three river diversions, that is, about $\$ 500$ million. The purpose of this article is to propose a practical wetland restoration effort involving these spoil banks.

Efforts to restore wetlands through hydrologic restoration are reasonable if there are strong and reversible cause-and-effect relationships between wetland losses and the hydrologic changes. This situation appears to exist in coastal Louisiana. Canals and spoil banks are the most likely cause of at least $30 \%-59 \%$ of

KEY WORDS: Wetland; Restoration; Dredging; Spoil; Louisiana

\footnotetext{
*Authors to whom correspondence should be addressed.
}

Louisiana's coastal wetland losses from 1955 to 1978 $(51,582 \mathrm{ha} / \mathrm{yr}$, or $0.85 \% / \mathrm{yr}$ ) (Turner and Cahoon 1987). Wetland losses may be due to either the direct or the indirect impacts of spoil banks and canals. Sixteen percent of these wetland losses resulted from the direct impacts of dredging wetlands into open water and spoil bank; at least $14 \%-43 \%$ of these wetland losses were the result of the indirect impacts of spoil banks and canals on water movement into and out of the wetlands. Another 13\% of the wetland losses were due to agricultural and urban expansion into wetlands.

Indirect impacts result from (1) longer wetland drying cycles, even in semi-impounded wetlands, as a consequence of altered water movements into and out of the wetland. [The lengthened drying periods promote soil oxidation and subsequent soil shrinkage (Table 1)]; (2) flooding events that may lengthen behind spoil banks (Table 1), prcsumably as a consequence of water being trapped behind the spoil bank once water enters overland during very high tides [When wetland flooding increases enough to seriously waterlog soils and then changes soil chemistry, plants may become stressed to the point where growth reduction or even die-back occurs (e.g. Babcock 1967, King and others 1982, Wiegert and others 1983, Men- 
Table 1. Changes in hydrologic regime of a semiimpounded saltmarsh ${ }^{a}$

\begin{tabular}{lcc}
\hline & Control & Semiimpounded \\
\hline Flooding & & \\
$\quad$ Number events per month & 12.9 & 4.5 \\
Event length (h) & 29.7 & 149.9 \\
Drying & & \\
$\quad$ Number events per month & 11.6 & 4.00 \\
$\quad$ Event length (h) & 31.2 & 53.9 \\
Mean water level (cm above & 1.71 & 3.99 \\
$\quad$ marsh surface; annual & & \\
average) & & \\
Volume exchange (m ${ }^{3 / m^{2}}$ & & \\
$\quad$ wetland surface) & & \\
$\quad$ Aboveground & 0.15 & 0.06 \\
Below ground & 0.09 & 0.04 \\
\hline
\end{tabular}

a(From Swenson and Turner 1987).

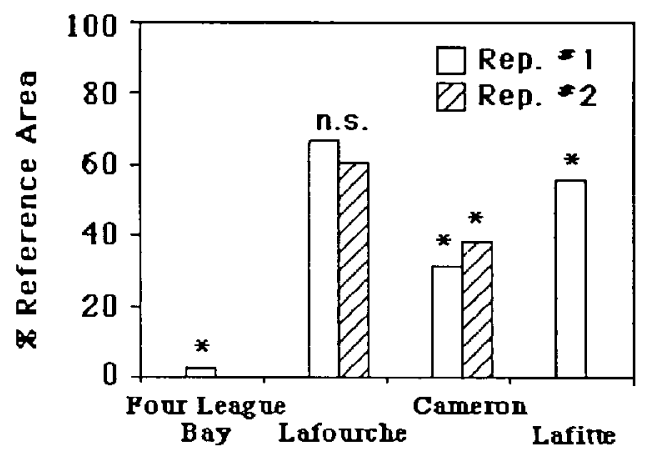

Figure 1. Vertical accretion rates in four hydrologically restricted areas (replicates, if available, are specific for each area and are designated Rep \# 1 and Rep \#2) compared to nearby reference sites. The data are from Fourleague Bay, Lafourche, Cameron, and Lafitte. Data were normalized to the control site values ( $100 \%)$. Asterisk by the bar indicates a statistically significant difference between the hydrologically restricted site and the control site. Adapted from Cahoon and Turner (1989).

delssohn and Mckee, 1987)]; (3) lower sedimentation rates behind spoil banks in any wetland type, because of the reduced frequency and depth of tidal inundation (Figure 1); and (4) in addition, the spoil banks consolidate the underlying soils. Water movements below ground are thus decreased, both because of the reduced cross-sectional area and the reduced permeability of material beneath the levee (Turner 1987).

The combined effects of sediment deprivation, increased wetland drying and lengthened soil flooding result in a hostile soil environment for plants. The death of plants reduces sediment trapping among the plant stems and accumulation of plant material at the soil surface and below ground. A shortfall in the vertical accumulation of soils (needed to balance the effects of a rising sea level and a sinking land) is the likely consequence. Small, shallow ponds may form and enlarge due to scouring under even light winds. The practical consequence of these causal mechanisms is a strong and direct relationship between wetland losses and canal density on a local and coastwide basis (e.g., Turner and Rao 1990).

\section{Issues in Developing Alternatives to Straight, Continuous Spoil Banks}

The area of existing spoil banks is very large compared to the area of spoil banks formed each year from new dredging activities. For example, the additional area of spoil bank added in 1991 was less than $0.4 \%$ of the total spoil bank area present in 1990 . One implication of this low percent is that wetland restoration efforts should be involved with the legacy of old spoil banks at least as much as with new permits.

Although wetland loss and spoil banks are regarded as interrelated by the academic community, landowners have a somewhat different perception. A canal and its associated spoil banks may improve access into the wetland. There is a potential for economic gain from petroleum, trapping, fishing, hunting, and alligators on land that traditionally had yielded little monetary return. Greater control of impounded habitats may result, and in many cases canals and spoil banks serve as tangible property boundary lines providing evidence of ownership like fences around rangeland. Many landowners do not perceive increased ponding as land loss, but rather as the price of doing business.

Although wetland restoration should be possible through spoil bank removal/manipulation (e.g., Gilmore and others 1981, Josselyn and Perez 1982, National Research Council 1991), questions may arise about areas in which to attempt restoration, who is going to attempt wetland restoration and under what circumstances, and about how the restoration efforts will be financed. Three relevant circumstances should be recognized: (1) There are fewer opportunities for off-site mitigation as the number of dredging permits issued is reduced each year as oil and gas reservoirs are depleted and the existing canal network or alternative recovery methodologies are utilized. (2) Landowners are essential participants in any spoil bank management plan. Landowners are the ones requesting/authorizing the request for dredging permits and have other interests in spoil banks in addition to mineral leasing. (3) There is a need to establish 
priorities for spoil bank restoration efforts; our knowledge is incomplete and we have little in the way of demonstration sites to use as examples of how the limited monies could best be spent.

It is the purpose of this article to outline an approach to identify and restore specific wetlands whose demise was probably related to the construction of spoil banks. We begin with a discussion of scveral potential candidate sites, identify gencral characteristics of suitable sites, and develop a modcl of what constitutes the appropriate amount of spoil material to be removed and another model of probablc costs.

\section{Materials and Methods}

\section{Examples of Potential Sites}

Three sites are discussed here as examples. These wetlands are classified as intermediate marsh, with typically low salinities, but with water levels affected by astronomical and meteorological tidal events. Site 7 (Jug Lake), located at lat. $29^{\circ} 21.9^{\prime} \mathrm{N}$, long. $90^{\circ} 57.4^{\prime} \mathrm{W}$, is immediately south of the western end of Jug Lake. Sites 34E (Mauvais Bois East) and 34W (Mauvais Bois West) are approximately $2 \mathrm{~km}$ north of site 7 , at lat. $29^{\circ} 23.5^{\prime} \mathrm{N}$, long. $90^{\circ} 57.4^{\prime} \mathrm{W}$ and lat. $29^{\circ} 23.4^{\prime} \mathrm{N}$, long. $90^{\circ} 58.0^{\prime} \mathrm{W}$, respectively. Vegetation transects were made at each site and in a reference site nearby. Water level gauges were deployed at five locations within the Jug Lake area. Two gauges were installed near site 7 , one gauge within the site and a second gauge in a reference area just east of site 7 along the bayou forming the southern boundary of the site. Three gauges were also installed near site 34 : one on the east side of the north-south canal within the middle of the site, one on the east side of the north-south canal that forms the western boundary of the site, and an openwater gauge in the north-south canal forming the western boundary of the site. In addition to water level, the open-water gauge near site 34 also measured temperature and conductivity.

Color infrared photographs from high-altitude photography of the coastal zone were used to estimate the percent of the site that appears as open water for each year. While the estimates of percent open water are not intended to represent fine-scale accuracy, for the time frame of 1952 to 1988 they do represent obvious trends (or the lack of trends) in open water/ wetland ratio. An additional site, Alliance, was examined photographically, but not in the field. This area is east of the Mississippi River, $50 \mathrm{~km}$ south of New Orleans.

\section{Size of Spoil Bank Changes}

We devcloped a generic model to estimate the size of an opening through a spoil bank needed for water speeds to equal natural flows over a marsh during an average tide. This model is a static model and is based on the total amount of water that moves off the marsh surface during a typical tidal cycle. Thus, the model yields one estimate of water speeds based upon the size of the marsh and the size of the openings through which the water is flowing. In reality, water flow on and off the marsh is dynamic and follows the water level forcing from the adjacent waterbodies. Tidal ranges of $10-20 \mathrm{~cm}$ (based on field data) were used. Tidal ranges may be lower farther into the marsh (the tide gauges were located about $40 \mathrm{~m}$ into the marsh) and higher during storm passages. $A$ concern about any hydrologic change is that higher than average current speeds may scour the marsh surface, thus reducing marsh elevation, or reduce accumulation of new sediment deposits. Based on field measurements of current velocity by ourselves and others (e.g., Lu 1991), we assumed that an undisturbed marsh had a desirable average flow of less than $5 \mathrm{~cm} / \mathrm{sec}$ flow across the marsh surface.

We assumed that the spoil bank cut would be about $0.25 \mathrm{~m}$ deep. The volume flux $\left(\mathrm{m}^{3} / \mathrm{sec}\right)$ is given by:

Marsh tidal prism $\left(\mathrm{m}^{3}\right) /$ tidal cycle length (sec) (1) which is calculated from:

[Area of marsh $\left.\left(\mathrm{m}^{2}\right)\right] \times$ [water depth on marsh (m)]/tidal cycle length (sec)

This water must flow through the gap (or gaps) in the spoil bank. The width of this gap will be determined so as to give a large enough cross-sectional flow area in order to keep the water speeds at the desired level. The water speed is given by the following:

$$
\text { Speed }(\mathrm{m} / \mathrm{sec})=\text { volume flux }\left(\mathrm{m}^{3} / \mathrm{sec}\right) /[\text { flow width }
$$$$
(\mathrm{m}) \times \text { flow depth }(\mathrm{m})]
$$

Rearranging yields the following formula for the flow width:

Flow width $(\mathrm{m})=$ volume flux $\left(\mathrm{m}^{3} / \mathrm{sec}\right) /($ flow depth

$$
\text { (m) } \times \text { speed }(\mathrm{m} / \mathrm{sec})]
$$

Substituting desired speed and depth yields the following formula for determining the desired width:

$$
\begin{aligned}
& \text { Flow width }(\mathrm{m})=\text { volume flux }\left(\mathrm{m}^{3} / \mathrm{sec}\right) / \\
& (0.25 \mathrm{~m}) \times(0.05 \mathrm{~m} / \mathrm{sec})
\end{aligned}
$$

Equation 5 was used to calculate the desired width for each site, using the measured marsh area $\left(\mathrm{m}^{2}\right)$ and the 
diurnal tidal cycle length of $12.5 \mathrm{~h}$. The equation was solved for various widths of cuts to generate a series of estimated current speed values. The cut widths were expressed as a percentage of the total spoil bank perimeter.

Some additional water movement is attributed to belowground flow and existing passageways out of the system. The actual flows should probably be less than $15 \mathrm{~cm} / \mathrm{sec}$ over the marsh. The actual amount of spoil bank to be moved is about $5 \%$ of the perimeter for these three marshcs. Naturally, the cube to square relationship of volume to surface area affects the amount removed. Larger parcels have a smaller perimeter-area relationship-a higher percent of the spoil bank must be removed to achieve the same hydrologic restoration.

\section{Costs}

We estimated the cost of restoring coastal wetlands under the conditions described above using the following cost estimates. We assumed that the spoil bank was the shape of a $0.75-\mathrm{m}$-high pyramid with a $2-\mathrm{m}$ base, to be cut $0.25 \mathrm{~m}$ into the marsh surface, and equal to approximately $1 \mathrm{cu} \mathrm{m} / \mathrm{m}$ linear length. Spoil removal was estimated at $\$ 1.40 / \mathrm{m}^{3}$ (based on current local rates). The desired average current speed in or out of the marsh during a tidal cycle was $5 \mathrm{~cm} / \mathrm{sec}$. Vegetation recovery was estimated at $50 \%$ of the open water area before project implementation, beginning with a project site of $80 \%$ open water. The restoration goal of $50 \%$ is justified on the basis of experience elsewhere (e.g., Gilmore and others 1981, Josselyn and Perez 1982). Furthermore, most restoration strategies explicitly and implicitly have a primary goal to restore the natural hydrology (National Research Council 1991). Dredge mobilization costs were estimated at $\$ 3000$, which was spread over 10 sites done sequentially.

We compared the cost of various sized restoration sites from this study with those of the: (1) Coastal Wetland Planning, Protection, and Restoration Act (PL 101-646) for coastal wetlands in Louisiana; (2) US Army Corps of Engineers wetland field demonstration sites by working units (these involve multiple sites for each working unit) [These costs are prorated per area of the total restoration site (not the anticipated gain in habitat). These projects are also cofunded by other agencies and involve additional costs]; (3) Mississippi River diversions (in Louisiana) currently under construction (US Army Corps of Engineers); and (4) three completed small river diversions (splays) at the mouth of the Mississippi River bird's-foot delta (Louisiana Department of Natural Resources).

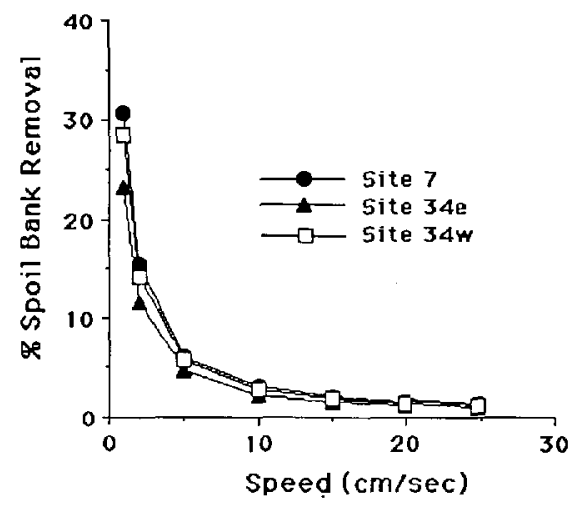

Figure 2. Hydrologic cut size vs average flow rate out of the site.

\section{Results}

\section{Hydrologic Model Results}

Some results from the hydrologic model are shown in Figure 2 for three example sites. Water flow through the spoil bank openings will be very sensitive to the size of the cut in the region of the desired flow velocity $(5 \mathrm{~cm} / \mathrm{sec})$. Underestimating the size of the cut necessary to achieve this flow may dramatically increase the average flow. Further, the percentage of the perimeter becomes larger with larger area (not shown), but, because the area-toedge relationship is nonlinear, the amount of perimeter removed becomes proportionately less with increased size.

\section{General Criteria for Site Selection}

Table 2 has 17 recommendations to improve site selection. There are thousands of new "holes" in these wetlands that formed over the last three decades (Turner and Rao 1990). However, these potential restoration sites are not equal in terms of the biological, physical, and sociological parameters necessary to achieve restoration. Hunting, fishing, and other landowner uses may be compromised, or thought to be compromised, temporarily by restoration. Shallow sites are more likely to recover faster than deep sites. Cost, landowner interest, and proximity to a high volume sediment source will have a bearing on project success and subsequent communication of the results to other landowners and managers. We were able to locate 50 potential sites within a few days using readily available photographic analyses and therefore are confident that there will be no shortage of places to try out this restoration method. 
Table 2. Recommendations for selection of possible spoil bank management sites

\section{Site characteristics}

Goal: Hunting and oyster leases should be maintained.

Rationale: To optimize cooperation, minimize legal complications from actual or perceived potential damages, and to reduce vandalism.

Goal: Marsh management plans (MMP) should not be compromised.

Rationale: MMPs are formal documents, already approved by state and federal agencies, with a perceived positive influence in the view of the applicants. It is possible to find alternative sites without this complication, and avoid possible conflicts and redundant application for permits.

Goal: Landowner cooperation is assured before the project starts.

Rationale: To simplify continuity, potential ancillary support services, and transfer of information.

Goal: Site accessibility.

Rationale: Maximize monitoring budgets and surveillance, although opportunities for vandalism might actually be lower in more remote locations.

Goal: Project size is appropriate for budget, personnel, and monitoring needs.

Rationale: One or two projects should not garner the majority of funds, especially in this early stage of understanding how well the approach will work in different habitats, substrates, and ownership patterns. "Strength through diversity."

Goal: Restored area less than $1 \mathrm{~m}$ deep.

Rationale: These are more likely to recover more quickly than deeper sites, since many plants will not root in deeper depths.

Goal: Areas with weirs and plugs should be avoided.

Rationale: The experiment should not be complicated by interpretations about whether or not additional water control structures hinder or help restoration.

Goal: Avoid the Intracoastal Waterway and other large navigation canals.

Rationale: The maintenance dredging effort is large and modification of the schedule and location is probably both cumbersome and unlikely and may affect interpretation of results.

Goal: Minimize dredging costs.

Rationale: To maximize use of funds. Off-site and on-site mitigation, utilization of agency dredges, exploring additional dredging postmobilization, and in-kind pro bono work may be additional ways to stretch the available dredging dollars.

2. Wetland type characteristics

Goal: Select sites from different salinity and vegetation regimes.

Rationale: Canals and spoil banks are present in all marsh types. It is desirable to investigate degrees of effectiveness of spoil bank removal in the various marsh types.

Goal: Select sites with proximity to a source of sediment.

Rationale: The more sediment available, the faster the restoration.

Goal: Select sites where a natural drainage network exists or can be reestablished.

Rationale: A natural dendritic network is more efficient at distributing sediment throughout the marsh by overbank flooding. Lack of a drainage network indicates natural impoundment and a sedimentation deficiency that may be difficult to overcome.

3. Substrate Characteristics

Goal: Select sites with firmer substrates.

Rationale: Increasing hydrologic exchange in a floating marsh may lead to the flushing of the vegetation and conversion of the site to open water.

4. Impoundment considerations

Goal: Maximize amount of marsh affected per volume of spoil removed.

Rationale: The action plan is to remove enough spoil to reestablish a natural hydrological regime where spoil deposits are blocking flow into and out of an area. An impounded area may be bounded on all four sides by spoil banks or by a combination of man-made and natural barriers (natural levees and abandoned distributary ridges). Impacting on site selection will be the type of spoil bank/canal system involved and the reason it was constructed in the first place. Some are for oilfield access, some are pipeline canals, and some are for agricultural, marsh management, or flood-control purposes. The type of canal system has a bearing on the height of the spoil bank and the amount of material that would be moved.

Goal: Avoid sites that are nested inside a larger impoundment.

Rationale: Since improved hydrological flow and access to sediment is key to marsh restoration, modification of spoil banks within a larger impounded area would not be cost-effective.

5. Other considerations

Goal: Maximize public trust of the project.

Rationale: Politically sensitive issues, such as boat ramp access, and legal controversies should be avoided to keep this project's objectives from being overshadowed or incorrectly compromised.

Goal: Make use of mitigation requirements to accomplish spoil bank removal.

Rationale: Developers and landowners who must offset wetland destroyed with a wetlands mitigation project might be allowed to fulfill that requirement by assisting with spoil bank removal. This will reduce costs and will increase interest in the project on the part of individuals and busincsses who can apply the techniques on other holdings. 

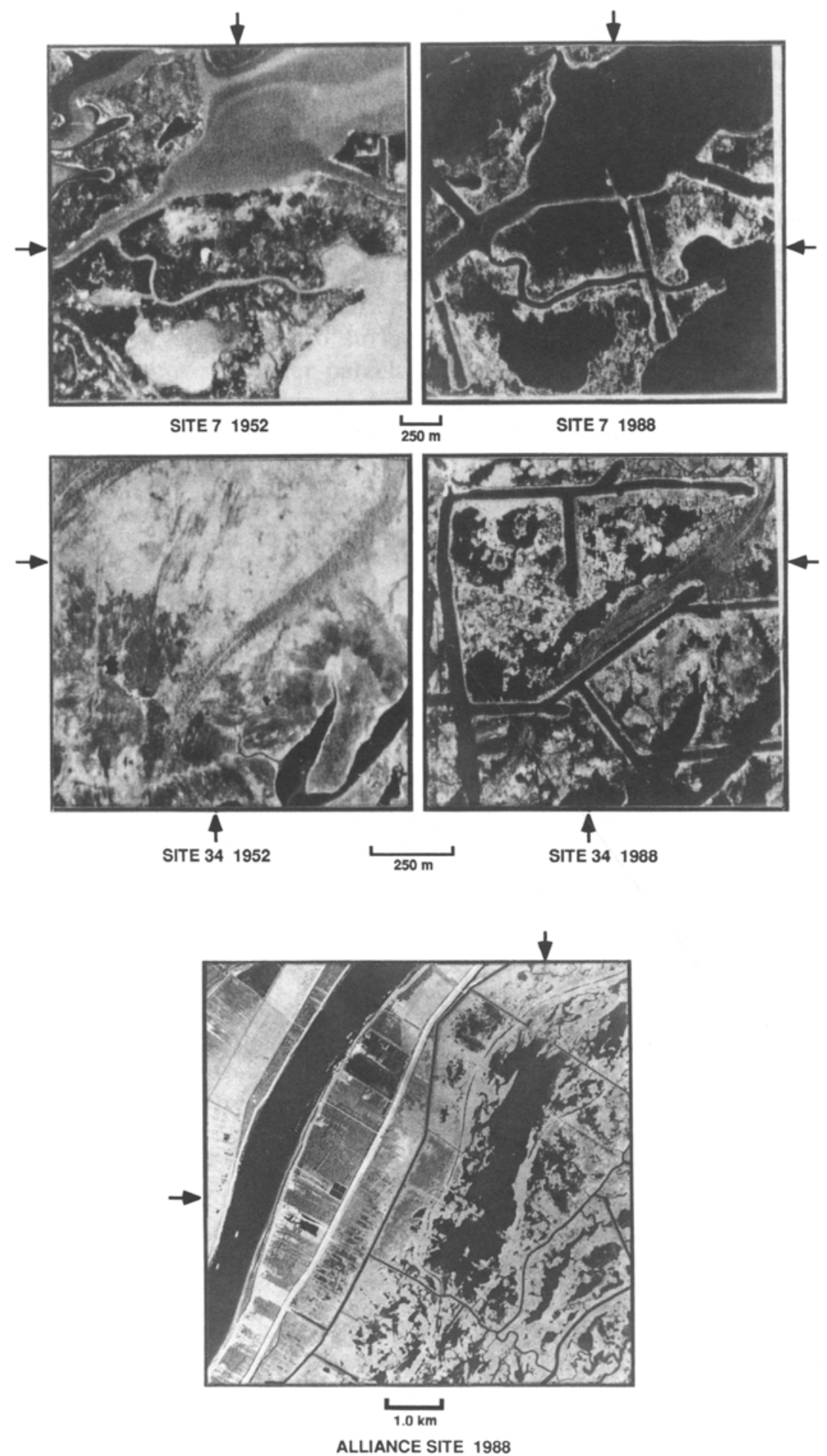

Figure 3. Photographs of the four sites mentioned as examples for possible spoil bank management: Jug Lake (7), $34 \mathrm{E}$ and $W$, and the Alliance site. Sites are indicated with arrows. 

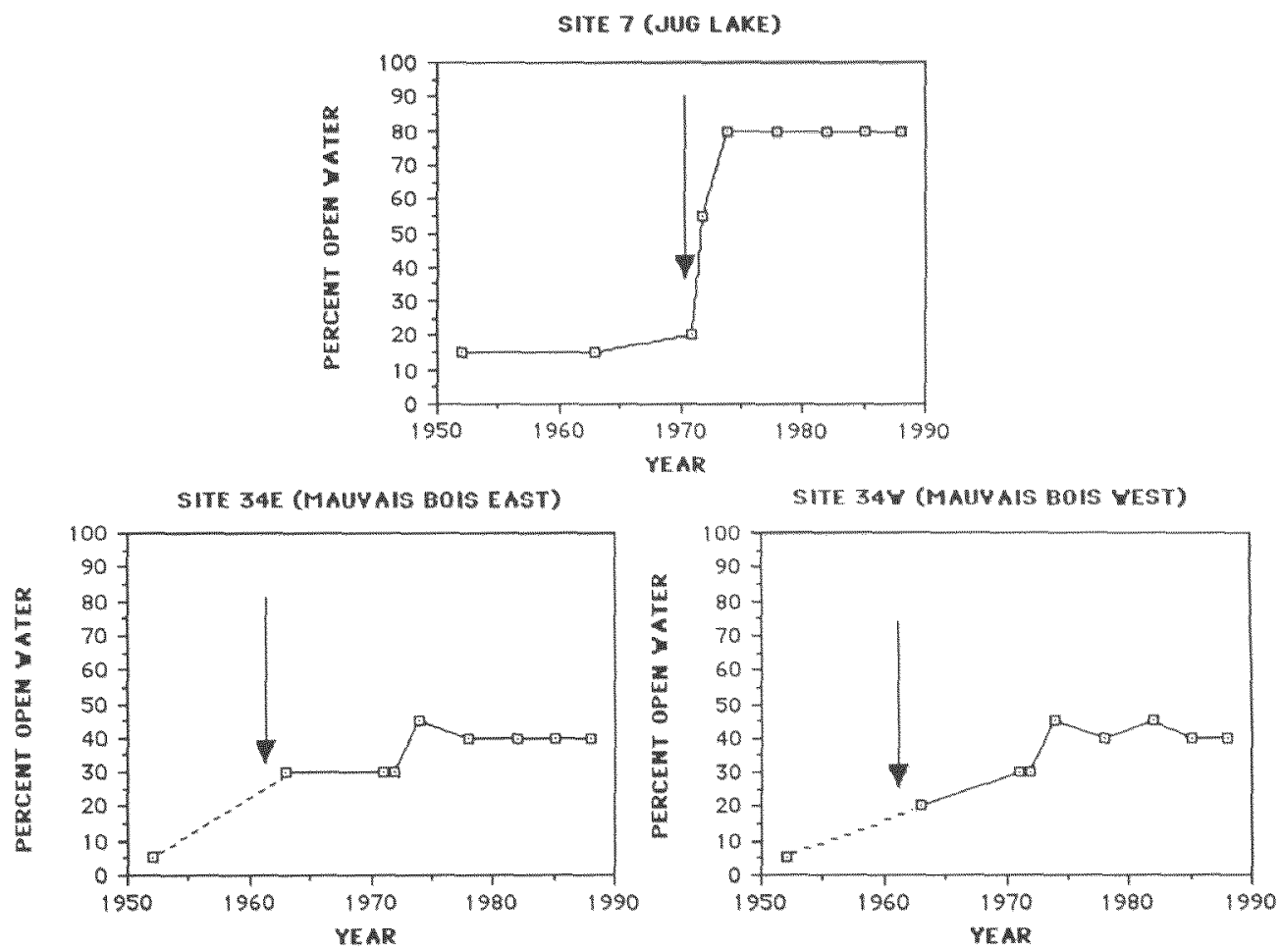

Figure 4. Changes in open water vs time for three example sites. The arrow marks the timing of the majority of dredging activity at each site. The data points are for the year aerial photographs were taken.

Example: Site 7 (Jug Lake) (Perimeter 3620 m, Including $2500 \mathrm{~m}$ of Spoil Bank)

Photographs of each of the example sites are shown in Figure 3 , changes in open water vs time are shown in Figure 4 , an example of water level fluctuations is shown in Figure 5 , a summary of the hydrologic conditions is given in Table 3 , and a recommended restoration scheme is outlined in Figure 6 and discussed in Table 4.

Site 7 was mostly marsh in 1952 (Figure 3 ) when we estimate the area of open water was $15 \%$ of the surface area. The canal that now forms the eastern boundary did not exist in 1952. No spoil deposits along the northern boundary (the Jugl Lake shoreline) were visible. The USGS 7.5' quad sheet (not shown), which is based on 1963 photography, also shows approximately $15 \%$ open water. The canal on the east ern boundary was permitted in October 1971 and dredged beween 13 February 1971 and 17 March 1972. The 1972 photography clearly shows the newly dredged canal with unvegetated spoil banks. It also shows the spoil deposits on the shoreline of Jug Lake. By 1974 the drilling site had been abandoned, eviw denced by plugs near the canal entrance at Jug Lake and on both sides of the intersection with the bayou that forms the southem boundary of site 7 . There also is a barge in the 1974 photograph, which now has a camp built on it; it is simated across the canal entrance at Jug Lake approximately 25 morth of the plug. The barge does not presently prevent water exchange between the canal and Jug Lake. We estmated that the interior of site 7 was $80 \%$ open water by 1974 . There has been little change in the land/water ratio or in the configuration of the marsh areas in site 7 beween 1974 and the present. The spoil bank on the eastern boundary appears to have been breached near the power line that was built by 1978 , although that portion of the spoil bank is noticeably narrower in 1972. The northernmost plug deteriorated between 1982 and 1985. That deterioration, combined with the breach of the spoil bank, allows some exchange between the interior of site 7 and Jug Lake.

Site 7 is almost certainly now open water because of the impoundment following the construction of a north-south spoil bank on the eastern border between 1971 and 1972. The development of open water is coincidental with spoil bank construction (Figure 4). A strengthened shordine protection levee 

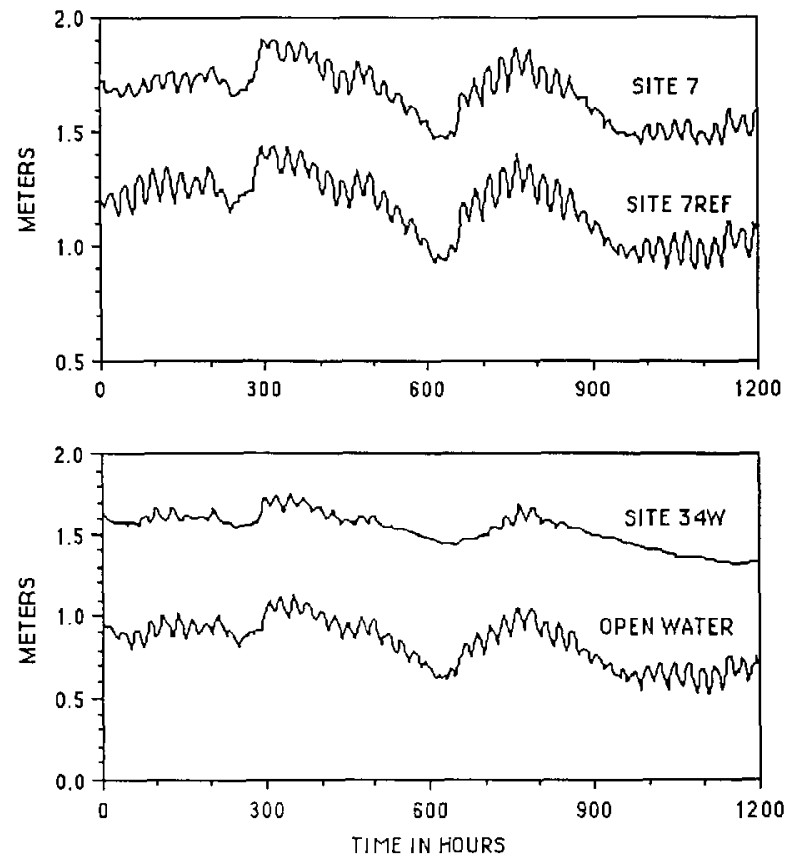

Figure 5. Examples of water level fluctuations at sites $34 \mathrm{~W}$ and 7 compared to the reference gauge in the nearby channel. Time begins 1 May 1991. Water level fluctuations in an unimpounded marsh are expected to have complete coincidence with water level fluctuations outside of the same marsh (e.g., Swenson and Turner 1987).

(now dredged) on the northern side blocks flow into the lake, and levees on the southern and western sides are very low. A barge blocks navigation, but not waterflow, on the northern end of the canal. A plug at the southern end of the canal could be removed to improve flow from Jug Lake.

In general, the area is not now particularly hydrologically impounded at high water levels, but there is an indication that water flow in and out of the area may be reduced during lower water levels. The purpose of the spoil bank removals is to reduce or remove the effects of impoundment, which may be more severe than appears with the present data set. The action would have the function of speeding up the process of restoration within the original study sitc. If the spoil bank on the eastern half of the canal wcrc opened, then the enlargement of the stream at the break site would not continue, in our opinion, thercby reducing loss rates there. A prototype restoration plan is shown in Figure 6a and described in Table 4. The purpose of the mat mentioned in the figure is to stabilize the cut and was included at the suggestion of the land manager.

\section{Examples: 34E and 34W (Perimeter $=4920 \mathrm{~m}$, Including about $4230 \mathrm{~m}$ of Spoil Bank)}

In 1952 none of the canals that define site 34 had been dredged (Figure 3). The Bayou Mauvais Bois abandoned distributary and its southern branch formed a distinct inverted $\mathrm{Y}$, open towards the southwest. The natural levees of the abandoned distributaries, the high ground in this environment, were forested, although the southern branch lost its identity (evidence that the natural process of subsidence was already at work) near the point where the northsouth canal now leads up from Jug Lake. What is now the interior of site 34 was overwhelmingly wetland, with just a few discernible pockets of open water. One distinct area of open water was in what is now the southwest corner of site $34 \mathrm{E}$, which remains open water at this time. Including this pond, less than $10 \%$ of the area of sites $34 \mathrm{E}$ and $34 \mathrm{~W}$ was open water in 1952 . The US Fish and Wildlife Service habitat map, based on 1956 aerial photography, shows the area to be dominated by "palustrine emergent vegetation" (Wicker 1980). The canals that define site $34 \mathrm{E}$ and 34W were dredged between February 1961 and March 1962. The USGS Lake Penchant $7.5^{\prime}$ topographic map (not shown), based on 1963 aerial photography, also shows that the canals were in place. That 7.5' quadrangle sheet also depicts areas of open water inside site 34 that were not present in the $195^{2}$ photograph. We were unable to locate aerial photographs, or interpretations, for the period between 1952 and 1960 . Loss of wetland progressed so that by 1974 , approximately $45 \%$ of both site $34 \mathrm{E}$ and $34 \mathrm{~W}$ were open water. That percentage has changed little since 1974 , although there have been some noticeable changes in the configuration of the ponds and wetland areas. Between 1974 and 1978, a trenasse (a ditch made by a fur trapper usually dug from and used by a small boat, or pirogue) appeared, coming from north of Bayou Mauvais Bois around the eastern terminus of the northern boundary canal and into the eastern tip of site $34 \mathrm{E}$. This trenasse still exists, providing a hydrologic link to a watershed from which site $34 \mathrm{E}$ was historically isolated.

It is clear from the water level records (an example for $34 \mathrm{~W}$ is shown in Figure 4 ) that sites $34 \mathrm{E}$ and $34 \mathrm{~W}$ were once impounded. Site $34 \mathrm{E}$ now appears to be more impounded than site $34 \mathrm{~W}$ (Table 3 ). A series of recommendations to restore the site is in Table 4 and outlined in Figure 6b.

\section{Example: Alliance}

The Alliance site (near the east bank of Mississippi River, across the river from the Alliance refinery and 
Table 3. Summary of water level results from 1991-1992 data collection

\begin{tabular}{lll}
\hline Site & \multicolumn{1}{c}{ Major findings } & \multicolumn{1}{c}{ Explanation } \\
\hline 7 & Water level fluctuations almost the same as bayou & 1. Site is not impounded during high water \\
water levels & 2 Limited data set (no spring data-low water) \\
& $\begin{array}{l}\text { W. Previously impounded, but levees now } \\
\text { disintcgrating }\end{array}$ \\
$34 \mathrm{E}, 34 \mathrm{~W}$ & $\begin{array}{l}\text { Water levels inside area coincidental with open } \\
\text { water only at high water levels }\end{array}$ & $\begin{array}{l}\text { 1. Both sites are impounded; overland flow } \\
\text { exchange occurs only when spoil banks are } \\
\text { topped }\end{array}$ \\
\hline
\end{tabular}

due east of the town in Phoenix in Plaquemines Parish) is bounded laterally by abandoned distributory ridges and impounded on either end by the spoil banks of dredged canals (Figure 3 ). The canals were present in February 1952, including the Back Levee Canal, to which the others connect, although the westernmost canal, now known as Horsepower Canal, was small, with negligible spoil deposits. We estimate open water to cover only $20 \%$ of the surface area between the distributary ridges at that time. The 1955/56 USFWS habitat maps (Wicker 1980) label the wetlands as palustrine emergent or estuarine intertidal emergent. By 1972 open water covered $70 \%$ of that total surface area. Horsepower Canal had been enlarged, with spoil banks evident in the photography. In the 1978 USFWS habitat maps (Wicker 1980) most of the area is classified as estuarine open water. The percentage of open water appeared to remain about $70 \%$ through 1988. The losses with this impounded marsh represent $>90 \%$ of all nearby wetland losses on that side of the river that occurred from 1933 to 1983 . This area appeared to become open water because of the impoundment, but to have a delayed deterioration compared to sites $7,34 \mathrm{E}$ and $34 \mathrm{~W}$.

\section{Cost Considerations}

The estimated costs of this restoration approach compare very favorably to other wetland restoration efforts, and there is an economy of scale (larger projects have a higher return per dollar expended than smaller projects (Figure 7). The restoration cost per hectare for projects $1-10,000$ ha ranges from $\$ 1000$ to $\$ 1$, respectively. The economy of scale is due both to the high mobilization costs for small projects and to the perimeter-area relationships affecting hydrologic flows. The cost of a 100-ha project equals the annual yield from fisheries landings (e.g., Farber and Costanza 1987).

These projected costs compare very well to the estimated restoration costs for existing programs, which are 100 and 1000 times higher in the case of inland wetland restoration programs and Coastal Wetland
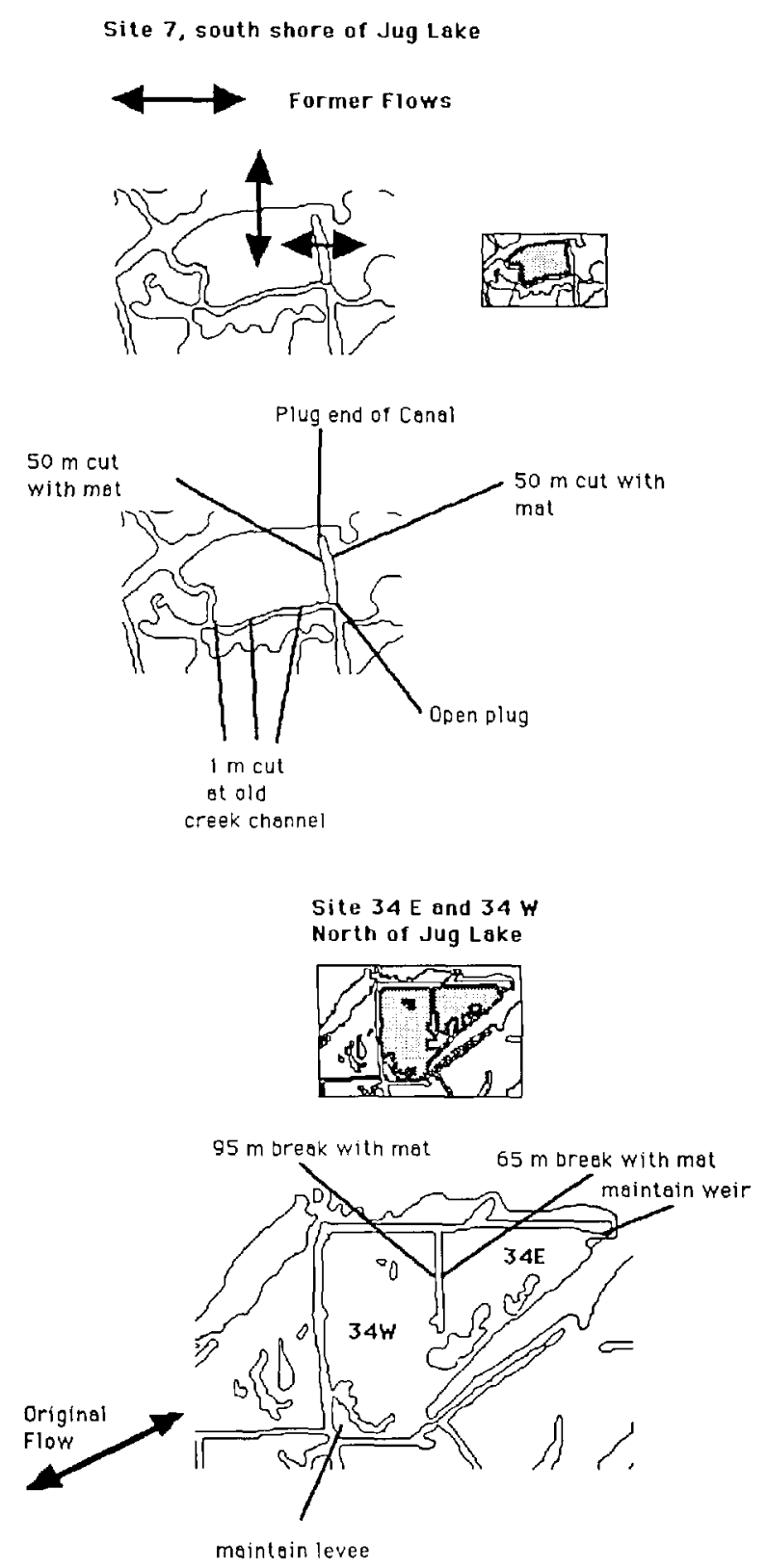

Figure 6. (a) Example of a possible restoration scheme for the Jug Lake site. (b) Example of a possible restoration scheme for the $34 \mathrm{E} / \mathrm{W}$ site. 
Table 4. Proposed actions for three example sites ${ }^{a}$

Site 7

Spoil bank cut of $50 \mathrm{~m}$ along the eastern boundary, across both sides of the spoil bank, to approximately $2 \mathrm{ft}$ below marsh level at the spoil bank, placing the dredge material either in the northern end of the canal (where the barge is now) or on the existing spoil bank. Alternatively, remove only parts of the spoil bank on western side of the $\mathrm{N} / \mathrm{S}$ canal.

Layer the bottom of the cut with an erosion-resistant "mattress."

Plug the northern end of the canal, perhaps using the spoil bank material dredged to make the cut.

Unplug the southern end of the canal on the eastern border, if the landowner is willing.

Perhaps, as an additional measure, make 3-m cuts at marsh level at three places along the southern border, where streams appear to have existed in the 1952 photograph.

Maintain the northern border as part of the normal shoreline stabilization program of the company.

The plug in southeast end of canal could remain, but is recommended to be opened, if at all possible. The northern plug is essential to keep navigation passage at zero, and to avoid flow from north to south eroding the spoil bank for reasons related to this project.

$34 \mathrm{E}$ and $34 \mathrm{~W}$

A spoil bank cut through the canal dividing the eastern from the western area, across both sides of the spoil bank, to approximately $2 \mathrm{ft}$ below marsh level at the spoil bank. The minimum cuts for $34 \mathrm{E}$ and $34 \mathrm{~W}$ should be 65 and $95 \mathrm{~m}$, respectively. It would be safer to make them even larger, but we assume there is some leakage out of the site already and that there is significant belowground flow.

Layer the bottom of the cut with an erosion-resistant "mattress."

Maintain the northern border as part of the normal shoreline stabilization program of the company.

Discuss with the landowner whether to replace the weir in the northeast corner with a plug.

Maintain the spoil bank in the southwest corner of the western section of the site.

${ }^{a}$ The fourth site discussed in the text (Alliance) is being evaluated for an alternative restoration scheme and was not examined further.

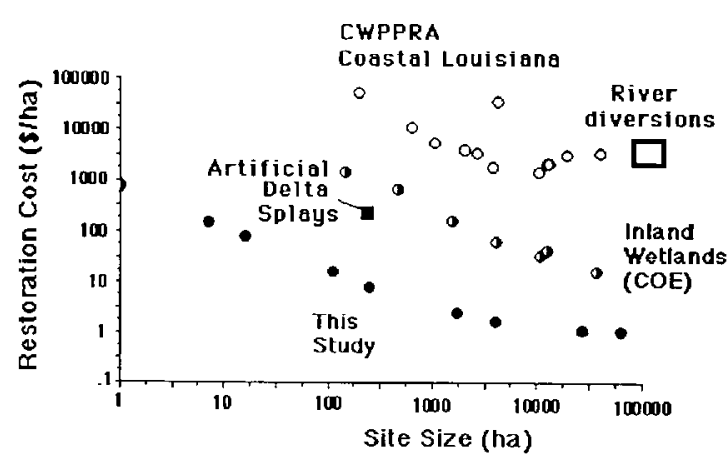

Figure 7. Examples of an economy of scale in different wetland restoration programs. Projects proposed under the Coastal Wetland Planning, Protection, and Restoration Act (PL 101-646) (CWPPRA 1992), USCOE wetland field demonstration sites by working units, this study, Mississippi River diversions (no site size given), and small river diversions (splays) at the mouth of the Mississippi River. The filled circles are from the model results of this study.

Planning, Protection, and Restoration Act (PL 101646) (CWPPRA 1992), respectively. Additional considerations are that the risks of wetland losses from an incorrect assumption or construction impact are minimized if the project starts with areas that are essentially $100 \%$ open water. Further, wetland restoration for areas $<1000$ ha are economical. Some of the CWPPRA projects have an undetermined possibility of not working, even causing wetland loss in the project site (e.g., marsh management project) (e.g. Cowan and others 1988, Cahoon and Groat 1990).

\section{Discussion}

Implementing a spoil bank management plan in coastal Louisiana is reasonable for two broad reasons. First, spoil banks are a likely agent of wetland loss, and, by implication, restoring natural hydrologic flows may reduce further losses and be an avenue for restoration of former wetlands. Second, the cost of restoration is several orders of magnitude lower than alternative programs in place, can be done in smaller areas, and with low risk of increased wetland loss for areas with mostly open water. Further, there are thousands of potential sites to choose from.

An outline of the desirable site characteristics is provided in Table 2. The demonstration projects should be completed with the cooperation and possible active involvement of the landowners, in order to best develop, use, and propagate any positive results of the effort.

Permitting actions provide opportunities to modify spoil banks under construction, to monitor the results, and to involve the permittees in the effort. Permit applications may be modified by the cooperating agencies to adapt to the needs of this project on a "permit-of-opportunity" basis. 
There are several ways to implement a spoil bank management plan:

1. Some landowners will initiate their own restoration measures if they understand that these will work. This result requires demonstration sites in some cases, but in other cases some landowners may willingly "experiment" to learn how to do things better.

2. Offsite mitigation is possible through the permitting process, at no additional cost to the state. However, new permitting decisions are best implemented if there are field examples to demonstrate that some success is likely.

3. Maintenance dredging may be denied in other cases (a permitting decision) allowing a de facto spoil bank deterioration.

4. The state, through the Coastal Wetland Planning, Protection and Restoration Act (PL 101-646) (CWPPRA 1992) can implement a matching "spoil bank restoration fund" for sharing costs with landowners, particularly in the beginning of the program when landowner cooperation is most valuable and resistance may be highest.

A prototype program is very valuable in this regard. The best use of the prototype plans will be early in the application of this new restoration approach. This effort should be scientifically strong and document plant, water, and soil properties in order to predict accurately the long-term consequences and successes of each restoration effort within a general framework. The first spoil bank removals/changes should be more extensively examined than the later ones.

Successful restoration using this approach will be dependent on several factors. Biological success will probably be dependent on water depth, flushing (or lack of it), the hydrology outside the site, sediment sources, and time. Social acceptability is partially dependent on issues related to drilling rights, hunting/ fur trapping and fishing uses, and who the landowner is and how the landowner is approached. Size is important because we want to maximize the effect of any restoration effort. Funding is important-because there is not money to remove all spoil banks-and permits could be modified with spoil bank manipulations as conditions of the permit and as mitigation for new dredge and fill activities.

Four types of manipulations should be considered (to be done after baseline measurcments):

1. Remove a small section of spoil bank, monitor changes, and then rebuild the section torn down;
2. Remove a small section of spoil bank, monitor changes, and remove another small section.

3. Remove sections of spoil bank to restore hydrologic flow below, above, and at the recommended amounts from the model, and to monitor changes in flow and restoration.

In summary, we propose an additional wetland restoration plan of broad applicability to wetlands ranging from one to thousands of hectares, with an excellent cost-benefit ratio and much lower projected costs than other programs that generally exclude wetlands $<100$ ha. The underlying rationale is based on strong scientific criteria implying causal relationships between hydrologic change and wetland loss. Desirable site characteristics are outlined, some preliminary recommendations made regarding spoil bank opening size, and three site-specific restoration plans are discussed.

\section{Acknowledgments}

This manuscript is the partial result of a joint statefederal subcommittee on spoil banks and canals comprised of representatives of the Louisiana Department of Natural Resources (DNR), the US Soil Conservation Service, the US Environmental Protection Agency, and the US Army Corps of Engineers. Significant financial support was provided by the Louisiana Sea Grant College Program.

\section{Literature Cited}

APHA, AWWA, WPCF, 1976. Standard methods for the examination of water and wastewater. American Public Health Association, 1015 Eighteenth Street NW, Washington, DC 20036, $1193 \mathrm{pp}$.

Babcock, K. M. 1967. The influence of water depth and salinity on wiregrass and saltmarsh grass. Unpublished PhD dissertation School Forestry and Wildlife Management, Louisiana State University, Baton Rouge, 109 pp.

Baumann, R. H., and R. E. Turner. 1990. Direct impacts of outer continental shelf activities on wetland loss in the central Gulf of Mexico. Environmental Geology and Water Resources 15:189-198.

Cahoon, D. R., and C. G. Groat (cds.). 1990. A study of marsh management practice in coastal Lousiana. Final report 0001-30410 to the Minerals Management Service, New Orleans, Louisiana. OCS Study/MMS 90-0075.

Cahoon, D. R., and R. E. Turner. 1989. Accretion and canal impacts in a rapidly subsiding wetland. II. Feldspar marker horizon technique. Estuaries 12:260-268.

CWPPRA 1992. Executive Summary, Coastal Wetland Planning, Protection, and Restoration Act. PL 101-646.

Cowan, J. H., Jr., R. E. Turner, and D. R. Cahoon, 1988 Marsh management plans in practice: Do they work in coastal Louisiana? Environmental Management 12:37-53. 
Farber, S., and R. Costanza. 1987. The economic value of wetland systems. Journal of Environmental Management 24:41-51.

Gilmore, R. G., D. W. Cooke and C. J. Donohoe. 1981. A comparison of the fish populations and habitat in open and closed salt marsh impoundments in east-central Florida. Northeast Gulf Science 5:25-37.

Josselyn, M., and R. Perez. 1982. Salt marsh restoration from salt evaporation ponds: Vegetation establishment and sediment properties. Page 100 in M. Josselyn (ed.), Wetland restoration and enhancement in California. California Sea Grant Program, University of California, La Jolla. Rep. T-CSGCP-007, 110 pp.

King, G. M., M. J. Klug, R. G. Wiegert, and A. G. Chalmers, 1982. Relation of soil water movement and sulfide concentration to Spartina alterniflora production in a Georgia salt marsh. Science 218:61-63.

Lu, T. 1991. Processes of sedimentation in the coastal marsh adjacent to a tidal bayou in south Louisiana. MS thesis. Department of Oceanography and Coastal Sciences, Louisiana State University, Baton Rouge, Louisiana, $80 \mathrm{pp}$.

Mendelssohn, I. A., and K. L. McKee. 1987. Spartina alterniflora die-back in Louisiana: Time-course investigations of soil waterlogging effects. Journal of Ecology 76:509-521.

National Research Council. 1991. Restoration of aquatic ecosystems. National Academy Press, Washington, DC, 552 pp.
Swenson, E. M., and R. E. Turner, 1987. Spoil banks: Effects on a coastal marsh water level regime. Estuarine and Continental Shelf Science 24:599-609.

Turner, R. E. 1987. Relationships between canal and levee density and coastal land loss in Louisiana. US Fish Wildlife Service Biological Report 85(14), 58 pp.

Turner, R. E. 1990. Landscape development and coastal wetland losses in the northern Gulf of Mexico. American Zoologist 30:89-105.

Turner, R. E., and D. R. Cahoon (eds.). 1987. Causes of wetland loss in the coastal central Gulf of Mexico, 3 vol. Final report submitted to Minerals Management Service, New Orleans, Louisiana. Contract No. 14-12-001-30252. OCS Study/MMS 87-0119,536 pp.

Turner, R. E., and Y. S. Rao. 1990. Relationships between wetland fragmentation and recent hydrologic changes in a deltaic coast. Estuaries 13:272-281.

Wicker, K. M. 1980. Mississippi deltaic plain region ecological characterization: A habitat mapping study. User's guide to the habitat maps. US Fish and Wildlife Service, Office of Biological Services, Slidell, Louisiana. FWS/ OBS-79/07, $45 \mathrm{pp}$, appendices, 464 maps.

Wiegert, R. G., A. G. Chalmers, and P. F. Randerson. 1983. Productivity gradients in salt marshes: the response of Spartina alterniflora to experimentally manipulated soil water movement. Oikos 41:1-6. 